\title{
KITAJSKI MIGRANTI IN COVID-19: MOBILNOST IN IZKLJUČEVANJE MED PANDEMIJO
}

Martina BOFULIN'

COBISS 1.01

\section{IZVLEČEK}

Kitajski migranti in covid-19: Mobilnost in izključevanje med pandemijo

Prispevek prinaša analizo mehanizmov izključevanja kitajskih migrantov med pandemijo covida-19. Avtorica najprej pokaže na značilnosti izključevanj in diskriminacije, s katerimi so se soočili kitajski migranti po izbruhu virusa tako v državah priselitve, v transnacionalni skupnosti in tudi ob povratku v državo izvora, kot tudi odzive na tovrstna dejanja med migranti. Avtorica ugotavlja, da so prav vsem oblikam izključevanja podložene specifične predstave o mobilnosti ter da je učinek tovrstnih izključevanj med drugim tudi reinterpretacija razmerja med dvojico »migrant - državljan«.

KLJUČNE BESEDE: kitajske migracije, covid-19, pandemija, diskriminacija, rasizem

\section{ABSTRACT}

\section{Chinese Migrants and COVID-19: Mobility and Exclusion in the Time of Pandemic}

The article analyzes the practices of exclusion and discrimination against Chinese migrants in the time of the COVID-19 pandemic. It highlights the mechanisms of exclusion towards Chinese migrants in the countries of settlement, the country of origin and their transnational communities as well as the resistance to discrimination. The author connects these practices to specific sets of mobility imaginaries and speculates about the effects of such exclusions in rearranging the relationship between the conceptual pair "migrant-citizen".

KEYWORDS: Chinese migration, COVID-19, pandemic, discrimination, racism

Dr. etničnih študij, znanstvena sodelavka; Inštitut za slovensko izseljenstvo in migracije ZRC SAZU, Novi trg 2, SI-1000 Ljubljana; martina.bofulin@zrc-sazu.si - Članek je nastal v okviru raziskovalnega programa »Dediščina na obrobjih« (P5-0408), ki ga financira Javna agencija za raziskovalno dejavnost Republike Slovenije. 


\section{UVOD}

Še pred razglasitvijo covida-19 za pandemijo 11. marca 2020 je nalezljiva bolezen zaustavila do tedaj običajni vsakdanjik. Globalna logistika ljudi in predmetov je skoraj čez noč zamrla v upanju, da bo zamrlo tudi širjenje virusa SARS-CoV-2. Nenadna in nepričakovana tišina, ki je nastala, je posledično izpostavila (ne)mobilnost kot enega nujnih elementov sodobnosti. Več kot desetletje star zapis priznanega raziskovalca mobilnosti Tima Cresswella se zdi skoraj preroški: »[...] mobilnost je arterija sodobnosti, kot tudi virus, ki grozi njenemu obstoju (Creswell 2006: 21). Pojasnil je, da je virus takrat uporabil kot metaforo za motnjo oz. turbulenco, kot jo je imenoval, obstoječim vsakodnevnim mobilnostim. Te so nam bile še do nedavnega samoumevne (Cresswell 2020). Z metaforo je želel ponazoriti, da naša življenja slonijo na samoumevni premisi, da je gibanje (ljudi, stvari, finančnih tokov itd.) vedno urejeno in predvidljivo. Kljub temu pa vsako gibanje vsebuje tudi potencial za motnjo, zaradi česar »turbulenca ni pokazatelj, da je sistem odpovedal, temveč da deluje« (ibid.).

$V$ tem smislu je sedanja pandemična turbulenca priložnost za spoznavanje logike in delovanja poznokapitalističnih sistemov, kjer hipermobilnost ni (bila) nujna samo za delovanje globalnega ekonomskega sistema, temveč tudi glavno gonilo sanj in aspiracij po boljšem življenju. Raziskovalcem migracij trenutni "zapik« omogoča prav poseben vpogled tako $v$ neenakosti, ki jih mobilnost poraja, kot tudi v kategorialni aparat, ki deluje kot osnova za razvrščanje mobilnih človeških usod. $V$ članku tvorjenje in vzdrževanje neenakosti med pandemijo opazujem iz izkušenj kitajskih migrantov $v$ treh različnih družbenih arenah: $v$ državah priselitve, $v$ njihovih transnacionalnih skupnostih in v izvorni državi. $V$ zadnjih desetletjih so številni prebivalci Kitajske postali zelo mobilni in so vzpostavili veliko medregionalnih in medcelinskih povezav, hkrati pa se soočajo z različnimi izključevalnimi govori, med drugim o "prenašalcih virusa« (pred covidom-19 že med izbruhom virusa SARS), ki je v mnogočem že nešteta ponovitev diskurza o »rumeni nevarnostik. Ker naj bi virus SARS-CoV-2 izbruhnil v kitajskem mestu Vuhan' ob koncu leta 2019, ${ }^{2}$ pa so bili tokrat postavljeni ne samo $v$ samo središče razvoja pandemije, temveč tudi $v$ središče govora o njej. Kot opozarja Cresswell (2020), so tako v preteklosti kot danes krivdo za bolezni pripisali ljudem od drugod, ki so jih že pred tem povezovali z različnimi negativnimi lastnostmi. Ti diskurzi z zelo realnimi učinki ne ogrožajo samo ekonomskega preživetja skupin in posameznikov, temveč pogosto tudi njihovo fizično varnost: $v$ zadnjih mesecih so bili posamezniki, na različnih delih sveta prepoznani kot »Kitajci«, tudi žrtve fizičnih napadov (Cheung, Feng, Deng 2020; Stolton 2020). Kitajski migranti se ne soočajo zgolj $z$ izključevanjem $v$ okoljih priselitve, kjer to običajno temelji na

1 V članku za transliteracijo kitajskih besed uporabljam mednarodno uveljavljeni sistem zapisa pinyin, razen $v$ primerih, ko sta beseda ali poimenovanje poslovenjena (npr. mesto Vuhan, ki se $v$ pinyinu zapisuje Wuhan).

Podatek o mestu in času izbruha SARS-CoV-2 povzemam po uradni razlagi Svetovne zdravstvene organizacije $z$ dne 1. 5. 2020. 
rasizmu, temveč tudi v svojih skupnostih in ob povratku »domov«, v izvorno državo, kjer pa je izključevanje drugače formirano. $V$ članku analiziram načine izključevanja, ki so med pandemijo še zlasti očitni, in se sprašujem o povezavi med izključevanjem in predstavami o mobilnosti v celotnem migracijskem procesu.

Kitajski migranti, ki jih vzpostavljam kot enoto analize, so zbirna kategorija za raznolike skupine ljudi, ki izhajajo iz Ljudske republike Kitajske. Med njimi se številne ločnice vzpostavljajo ob robu državljanstva (naturalizacija ali ohranitev izvornega državljanstva), načina migracije, finančnih zmožnosti oz. pripadnosti družbenemu razredu, lokaciji izvora na Kitajskem in življenjskem stilu. Smiseln je premislek o upravičenosti oz. celo smislu izbora tako neenotne enote analize, še zlasti glede na pozive o preseganju metodološkega nacionalizma (Wimmer, Glick Schiller 2002), ki najpogosteje »domuje " prav v izpostavljanju določene skupine migrantov in omejitvi družbenih svetov subjektov na lastno skupino ali meje države priselitve. $V$ tem primeru nam osrediščenje na kitajske migrante omogoča vpogled $v$ številne, čeprav različne mehanizme izključevanja na vseh relevantnih »lokacijah« migracijskega procesa - v državi izselitve, državi priselitve kot tudi v transnacionalnih družbenih prostorih - ki so $v$ veliki meri postali tako očitni prav zaradi izbruha virusa na Kitajskem.

Metodološko članek temelji predvsem na podatkih, ki sem jih pridobila po elektronskih medijih - med januarjem in aprilom 2020 sem spremljala razprave in objave na kitajskih socialnih omrežjih (Wechat) in drugih medijih (mikroblogovska platforma Weibo, kitajski in nekitajski spletni portali in časniki). Po socialnih omrežjih sem zaradi ukrepov prepovedi gibanja za zajezitev covida-19 v Sloveniji stopila v stik s sogovorniki iz predhodnih raziskav. K pisanju članka me je spodbudila vest, da je marca 2020 zaradi covida-19 preminil sogovornik iz preteklih raziskav, ki mi je nudil namestitev na Kitajskem med enim izmed mojih raziskovalnih obiskov. Ta zapis zato posvečam njemu in številnim drugim migrantom, ki jim je pandemija covida-19 na tak ali drugačen način posegla $v$ njihova življenja.

\section{"JAZ NISEM VIRUS, SEM OSEBA« - DISKRIMINIRANI KITAJSKI PRISELJENCI}

Kmalu po prvih informacijah o širjenju skrivnostnega virusa v provinci Hubei na Kitajskem januarja 2020 so se pojavila poročila iz različnih delov sveta o primerih rasizma in ksenofobije, usmerjenih proti osebam kitajskega izvora oz. s kitajskim ozadjem. Previdni odzivi v obliki fizičnega oddaljevanja, za katerega se je med pandemijo uveljavilo poimenovanje »družbeno oddaljevanje«, od posameznikov, zaznanih kot "Kitajci«, in verbalni napadi nanje so kmalu prerasli v fizično agresijo. V grobem bi dejanja lahko razvrstili v tista, ki ogrožajo ekonomsko dejavnost priseljencev, in tista, ki ogrožajo njihovo fizično varnost.

V prvo skupino sodi prenehanje obiskovanja kitajskih restavracij in trgovin, saj se nanje gleda kot na žarišča prenosa virusa. O praznih restavracijah, izginotju vrst pred vhodom in upadu rezervacij so še pred uveljavitvijo ukrepov za preprečevanje 
širjenja virusa poročali tako v Evropi, Avstraliji kot ZDA (glej raziskavo vedenja potrošnikov Ipsos Mori 2020), čeprav je obseg upada števila gostov in zaslužka težko oceniti. Raziskava, ki jo je v ZDA izvedel Wompy, ameriški ponudnik programske opreme za majhna podjetja, je odkrila povezavo med »odkritjem « prvega primera koronavirusa $v$ ZDA in upadom obiska kitajskih restavracij, ne pa tudi drugih restavracij, zaradi česar je zaključila, da lahko govorimo bolj o ksenofobiji kot germofobiji (Wompy 2020). Poleg upada obiskov so se pojavili tudi aktivisti, ki so aktivno pozivali k blokadi kitajskih lokalov. V severni Italiji na primer so se na kitajskih trgovinah čez noč pojavili plakati z logom ekstremistične skupine Forza Nuova: »Koronavirus? Kupujte italijansko. To je naša moralna dolžnost« (Liu 2020).

Med izključevalnim vedenjem je bilo opazno izogibanje osebam, zaznanim kot »Kitajci«, mdr. v zdravniških ordinacijah, javnem prometu ter v šolah, tako v Evropi kot tudi ZDA in Avstraliji (Campbell 2020; Govan 2020). Prav tako so bili (kitajski) priseljenci tarča številnih verbalnih napadov tako v vsakdanjem življenju kot na svetovnem spletu in socialnih omrežjih (Macguire 2020). Diskriminatorni in rasistični pozivi pa se niso pojavljali zgolj med »nepoučeno množico«, temveč so jih razširjali tudi predstavniki oblasti. Mednje se na primer uvršča zapis župana severnoitalijanskega kraja Solto Collina Maurizia Estija: »Ti $j^{* * * *}$ Kitajci, oni jedo vse. Netopirje, kače, pse in insekte, oni bi morali biti edini, ki bodo umrli v tej epidemiji« (Puente 2020). Vsaj v Italiji ta kritika ni bila osamljena. Tudi zaradi tovrstnega govora predstavnikov oblasti se napadi niso ustavili le pri žaljivkah, temveč so ponekod prerasli v fizično nasilje.

Dejanja, naperjena proti »prenašalcem virusa«, niso bila usmerjena zgolj proti Kitajcem, temveč kar proti vsem osebam s sorodnim fenotipom; med žrtvami so bili Japonci, Filipinci, Tajci, Korejci, seveda pa tudi Italijani, Angleži, Nemci in pripadniki drugih narodnosti s predniki iz Azije. Storilcev tudi ni zanimalo, ali so bili ti ljudje sploh $v$ tujini ali imeli stike $z$ nedomačini. Skladno s klasičnim pojmovanjem rasizma je že »vidna razlika« akterja zadoščala za pripis tujosti in posledično nevarnosti. Tako so $v$ bližini Milana napadli Filipinko, za katero so menili, da je Kitajka (CNNPhilippines), vandalizirane so bile japonske restavracije (The Straits Time), v Londonu je moral, da ne bi prestrašil obiskovalcev, odstopiti vietnamski kustos umetniškega sejma (Busby 2020), če omenim le nekaj primerov. Tak odziv je samo okrepljena različica odnosa do ljudi azijskega porekla med letoma 2003 in 2004, ko se je svet spopadal z epidemijo virusa SARS (Hung 2004; Leung 2008) ali bubonske kuge na Havajih in v ZDA na prelomu stoletja (Kalisch 1972). Tudi takrat je bilo mogoče opaziti presenetljivo podobne odzive večinske družbe do oseb kitajskega / azijskega videza. Tovrstna izključevanja se tudi danes v veliki meri okoriščajo z elementi rasističnega diskurza o »rumeni nevarnosti«, prisotnem v družbah t. i. Zahoda že vsaj 150 let.

Kot odziv na tovrstne napade je vzniknila kampanja »Jaz nisem virus«. V Italiji je Massimiliano Martigli Jiang, ki se je $v$ Italijo kot sedemletni otrok priselil iz province Zhejiang na vzhodu Kitajske, na socialnih omrežjih začel objavljati kratke posnetke. $V$ njih pred različnimi turističnimi znamenitostmi Firenc $z$ masko in $s$ prevezo čez oči stoji ob dvojezičnem napisu »Jaz nisem virus, sem človek. Osvobodite se 
predsodkov." (Io non sono un virus, sono un essere umano. Liberami dal pregiudizio. / Wo bu shi bingdu, wo shi renlei. Bu yao dui wo you qishi.) Objave so dosegle širok krog uporabnikov spleta in socialnih omrežij ter sprožile spontano javno podporo proti nadaljnji diskriminaciji (Chen 2020). Podobno so mladi Francozi azijskega porekla začeli kampanjo \#JeNeSuisPasUnVirus, da bi opozorili tako na javne diskurze kot tudi vsakodnevne izkušnje ksenofobije do oseb azijskega videza v francoski družbi (Coste 2020). Odzivi na pandemijo tako nadaljujejo prizadevanja priseljencev iz Kitajske in drugih delov Azije ter njihovih potomcev za enakovreden položaj v evropskih družbah priselitve.

Poleg aktivističnega boja proti diskriminaciji pa so odzivi kitajskih priseljenskih populacij v Evropi zaznamovani tudi s skrbjo pred širjenjem nadaljnje okužbe in previdnostjo. Ker je izbruh virusa na Kitajskem časovno sovpadel s prazniki ob lunarnem novem letu, ko so mnogi obiskali svoje sorodnike na Kitajskem, so bili ob povratku v Evropo zelo zaskrbljeni zaradi manjka ukrepov za zajezitev širjenja virusa. V Italiji naj bi se po poročanju medijev številni takoj po prihodu iz Kitajske zaprli v strogo samoizolacijo, otroci pa so prenehali obiskovati šole že tedne pred njihovim uradnim zaprtjem (Ceccagno, Salvati 2020). Zato naj bi npr. mesto Prato, kjer živi največje število kitajskih priseljencev v Italiji, ne imel niti ene same okužbe s covidom-19 (Ognibene 2020).

Podobno je bilo opaziti tudi v Sloveniji. V več primerih so kitajski priseljenci, ki so se februarja vrnili iz Kitajske, poskušali stopiti v stik z odgovornimi na Letališču Jožeta Pučnika ali pa s Kliniko za infekcijska obolenja. Ker v tistem času še ni bilo ukrepov za zajezitev covida-19, so ostali prepuščeni sami sebi. Po platformi Airbnb so najeli stanovanja in se za 14 dni zaprli v samoizolacijo, medtem ko so jim domači zgolj prinašali hrano, in to tako, da z njimi niso prihajali v stik. Mnogi izmed kitajskih priseljencev tudi v času ukrepov za zajezitev virusa niso zapuščali svojih bivališč niti za odhod $v$ trgovino ali na sprehod. ${ }^{3}$ Kitajski migranti v Sloveniji in tudi drugje so torej prakticirali fizično oddaljenost in izolacijo kot zaščito zase in za sredine, $v$ katerih prebivajo, še preden je to postal eden poglavitnih ukrepov številnih držav proti širjenju virusa. Kljub temu je bila tovrstna »družbena odgovornost« povečini spregledana, še več, nakupovanje in nošenje zaščitnih mask sta bila pogosto tolmačena ravno obratno; prvo kot špekuliranje za poznejšo prodajo, drugo kot priznanje, da so virus širili prav oni (Weale 2020).

Kljub temu da nekateri kitajski migranti in njihovi potomci že desetletja prebivajo $v$ državah priselitve, so pridobili državljanstvo in se počutijo kot domačini ali pa so se $v$ teh državah celo rodili in odrasli, so čez noč postali tisti, ki se jih je treba izogibati in bati. Rasizem se je silovito dvignil nad tiste, ki jih večinsko prebivalstvo na podlagi zunanjega videza uvršča v skupino »od drugod« in jim zato pripisuje mobilnost in $\mathrm{s}$ tem tudi večjo bližino virusa.

3 Podatki so bili v neformalnih pogovorih s sogovorniki v Sloveniji pridobljeni februarja, marca in aprila 2020. 


\section{„ČE NE ZMORETE SOČUSTVOVATI ALI POMAGATI, VSAJ NE POVZROČAJTE ŠE VEČ GORJA« - IZKLJUČEVANJE ZNOTRAJ SKUPNOSTI}

Poročanja o ksenofobiji in rasizmu, s katerimi so se morali med pandemijo soočati kitajski priseljenci $v$ državah naselitve, so po množičnih medijih dosegla širok spekter javnosti tako v državah priselitve kot tudi na Kitajskem. O procesih v priseljenskih skupnostih, kjer so posamezniki ali družine lahko zaradi suma o kužnosti ali prisotnosti koronavirusa prav tako izključeni, pa vemo bistveno manj. Morda so to najobčutljivejše oblike izključevanj, ki posežejo globoko v posameznikovo intimno sfero in njegovo najožjo družbeno mrežo. To niso dejanja verbalnega in fizičnega nasilja, temveč »tiho izključevanje«, predvsem v obliki govoric, ki se širijo ne samo v kraju priselitve, temveč tudi v kraju izvora in v celotnem transnacionalnem prostoru, ki ga določena skupnost vzdržuje. Kot menita Ron Barrett in Peter Brown (2008), je stigma zato več kot le negativen sopojav določenih bolezni, saj deluje kot posebna vrsta bolezni in ima lahko tudi podobne smrtonosne učinke kot "fizična« bolezen, zaradi katere se je pojavila. V nadaljevanju navajam primer, ki je močno odmeval na različnih lokacijah transnacionalnega prostora Qingtiancev, številčne skupine kitajskih migrantov v Evropi, s katero jih povezuje več kot stoletna migracijska zgodovina.

Marca 2020 je po kitajskem socialnem omrežju Wechat zaokrožila fotografija urejenega starejšega para, fotografiranega pred neimenovano fontano. Na fotografiji je bilo v kitajskem jeziku zapisano ime moškega s podatki, koliko let je preživel v Evropi in da je pred nekaj dnevi v bolnišnici v velikem evropskem mestu preminil kot »prva žrtev covida-19 med kitajskimi priseljenci v Evropi«. Obširni intervju s hčerkama para, objavljen na straneh uradne skupine Weicheng na Wechatu, namenjene kitajskim priseljencem $\vee$ Evropi, ne pojasnjuje samo okoliščin njegove bolezni, temveč tudi odzive skupnosti na prisotnost covida-19 med njenimi člani (Weicheng 2020).

Par se je sredi februarja 2020 udeležil dvotedenskega križarjenja po Mediteranu. Že ob odhodu naj bi gospod trpel za bronhitisom, njegovo stanje se je nekaj dni po prihodu na ladjo izboljšalo. Pred koncem križarjenja pa je zopet začel kašljati. Dobil je vročino, za katero so mu na ladji priporočili protivročinska zdravila. Ker se je v tem času o izbruhu virusa veliko govorilo tudi v Evropi, jima je hčerka po posvetu z družino in s poslovnimi partnerji predlagala, da gresta po vrnitvi domov $v$ strogo samoizolacijo. Po njenem pričanju starši sicer niso sumili, da so okuženi, vendar so se strinjali s predlaganim ukrepom. $V$ ta namen je hčerka najela nadstropje $v$ hiši na obrobju kraja prebivanja in pripravila potrebno hrano, razkužila in druge stvari za njuno izolacijo. Po izkrcanju se je par s skupnim večurnim avtobusnim prevozom vrnil na izhodiščno točko ter se s taksijem pripeljal do najetega stanovanja. Oba sta se v naslednjih dneh počutila vse slabše, zato je hčerka poklicala rešilca. Odvzeli so jima vzorce za test o prisotnosti virusa SARS-CoV-2; pri obeh je bil izvid pozitiven. Odpeljali so ju v bolnišnico, kjer je on že čez nekaj dni umrl. Že takoj po njuni hospitalizaciji se je novica o njuni bolezni bliskovito razširila po spletu, predvsem po različnih skupinah na socialnem omrežju Wechat in predvsem med člani qingtianskega transnacionalnega prostora. 
Po poročanju omenjenega medija so se začele vrstiti obtožbe na njun račun, češ da sta se na poti nazaj ustavila pri prijateljih v manjšem mestu in tudi tam morebiti okužila ljudi, da sta se po vrnitvi družila s prijatelji, da sta obiskala tržnico, predvsem pa, da sta bila v stiku z družinskimi člani in sta še naprej delala v družinskem podjetju. Hči je vse obtožbe zavrnila in novinarju pokazala dopisovanje s starši, ki naj bi dokazalo, da se je, čeprav ji je bilo zelo težko, stiku z njima izogibala:

Medtem ko sem sedela v svojem avtu, sem videla svoja starša, kako bleda in tresoča le s težavo nosita prtljago do hiše. Jaz pa sem ju lahko le gledala od daleč! [...] Nihče ne more razumeti, kako grozno sem se počutila in kako sem si želela, da bi jima prihitela pomagat! Zelo, zelo sem trpela, vendar sem se zadržala. Vedela sem, da bi bilo potem vse to zaman! (Weicheng 2020)

Hči je zatrdila, da starša nista bila v stiku z nikomer, predvsem zato, ker sta hotela »ohraniti obraz« (tj. ohraniti čast in dobro ime) ter se ne izpostaviti z morebitno prisotnostjo virusa. Najbolj pa naj bi jo prizadele zlobne misli posameznikov, ki so na medmrežju na primer zapisali: „Da v tem času odideš na križarjenje! Če sta že morala oditi, zakaj nista raje kar tam umrla in se ne vračala ..." Kot je povedala novinarju, je bila zaradi takšnih zlobnih govoric popolnoma obupana. Po njenem mnenju bi take male skupnosti morale $v$ času preizkušenj stopiti skupaj, predvsem pa upati, da pacienti okrevajo, ne pa sprožati novih govoric in prizadejati še več bolečine. Prav tako je izrazila veliko zaskrbljenost, da bodo za vse prihodnje okužbe v mestu okrivili njena starša. Svojo pripoved je končala $\mathrm{z}$ besedami:

Kljub temu da smo upoštevali zaščitne ukrepe, smo tudi mi sedaj nesrečne žrtve, ki jih želijo vsi kaznovati. Ne strinjam se s tem, da je bila moja družina zaradi diagnoze osramočena. Sedaj se počutim le žalostno in obupano. Ne samo, da sem prizadeta jaz, moja družina in vsi okoli mene so prizadeti! [...] V tem trenutku bi vsakdo moral krepiti svojo imunost in paziti nase, ne pa razmišljati o tem, kako bo prizadel druge. Če ne morete sočustvovati ali pomagati, vsaj ne povzročajte še več gorja. (lbid.)

Kot je bilo zapisano v uvodu internetnega članka, je namen intervjuja "pojasniti dejstva« okoli pojavljajočih se govoric. Hkrati je obsežen del poročanja namenjen prikazovanju pravilnega vedenja ob srečanju z virusom. Ta prikaz med drugim kritizira lokalno prebivalstvo, vključno z zdravstvenim osebjem, ker niso nosili mask in druge zaščitne opreme in niso bili pripravljeni na ravnanje s pacienti, obolelimi za virusom. Hkrati zapis tudi sporoča, da ne par in ne njuna družina nista v ničemer ogrozila drugih pripadnikov skupnosti ali sokrajanov. Še več, glede na poročanje bi z zelo strogimi ukrepi, ki so jih samoiniciativno izvedli, lahko bili tudi zgled za soočanje z virusom, ki svojih žrtev ne izbira.

Pritisk članov skupnosti in posledična stigma sta presenetljiva le na prvi pogled. Kot je zapisal že sociolog Erving Goffman (v Pescosolido, Martin 2015), žrtve 
stigmatizacijo vedno občutijo $v$ konkretnih družbenih odnosih, sama stigma pa je kontekstualna, vezana na specifični prostor in čas ter arbitrarna, razkriva pa prelome, ki se pojavljajo v določeni družbeni skupini. Zaradi tega skupnosti za svoje člane niso vedno varen pristan, temveč polje številnih in kompleksnih iger moči. Poleg tega na migrantske skupnosti vpliva tudi marginalen in podrejen status $v$ večji družbeni enoti (npr. državi priselitve), kjer pripadniki Drugega dobro vedo, da so vedno opazovani ter da so njihova dejanja vedno pod drobnogledom. Takšna razmerja moči med krizo, kot je pandemija, postanejo še izrazitejša. Gre za nasilje, ki rodi nasilje, take skupnosti namreč pogosto stigmo, ki so jo deležne »od zunaj«, tj. od večinske družbe, usmerijo »navznoter«, tj. proti svojim članom.

\section{„VELIKI OTROCI« - KITAJSKI IZSELJENCI SE VRAČAJO DOMOV}

Potem ko je kitajska vlada 18. marca 2020 objavila, da v državi ni več lokalnega prenosa okužbe virusa SARS-CoV-2 (Reuters), se je država kmalu soočila z domnevnim naraščanjem t. i. »uvoženih« primerov. Virus naj bi namreč prenašali ljudje, ki so se na Kitajsko vračali iz tujine. Med temi bi lahko razločili tri skupine. Največ je bilo študentov, ki so se na Kitajsko iz tujine vračali po prekinitvi študijskega procesa ali pa so se morda morali izseliti iz študentskih namestitev, morda pa se v državah študija niso počutili varne (npr. zaradi diskriminacije ali preveč milih ukrepov za zajezitev virusa; Weale 2020). V drugi skupini so bili kitajski izseljenci, ki so se vrnili predvsem zato, ker so v tujini zaradi protikoronskih ukrepov izgubili službo ali zaradi družinskih obveznosti. V tretji, najmanjši skupini so tuji državljani nekitajskega porekla, ki bivajo ali delajo na Kitajskem. Ukrepi za preprečevanje širjenja virusa, ki so naslavljali povratnike, so bili sprva precej ohlapni, vendar pa je zaradi naraščanja "uvoženih « primerov in izogibanja prostovoljni karanteni država hitro napovedala dosti strožje ukrepe in tudi javno poudarila odgovornost povratnikov $v$ boju proti virusu (Qiu, Yue 2020).

$V$ istem času so se na spletu in socialnih omrežjih pojavili posnetki posameznih povratnikov, ki se ukrepov proti širjenju virusa bodisi niso držali bodisi so bili do njih kritični. Teh nekaj primerov, ki so preplavili medijsko krajino, je povzročilo histeričen odziv uporabnikov socialnih omrežij in mikroblogovskih platform. Srd t. i. kitajskih netizenov je na Kitajskem močno orodje javnega mnenja, ki ga ne more spregledati niti oblast (Zhou 2011). Najmočnejši odziv sta povzročila posnetka mlajših povratnikov iz Italije. Na prvem moški v kitajskem jeziku s qingtianskim naglasom pokaže razmere na letališču ob vrnitvi $v$ državo, kjer je zaradi testiranja prišlo do gneče in večurnega čakanja v (pre)tesnih prostorih. Na posnetku komentira:»Poglejte [...] Nas, ki smo se vrnili iz Europe, tako tretirajo ... (Kankan [...] Women cong Ouzhou huilaide daiyu shi zheyangde ...) (Youtube 2020a). Na drugem posnetku je mlajša ženska, ki je, glede na posnetek, po vrnitvi iz Italije v karanteni in prosi varnostnike, če bi ji lahko prinesli ustekleničeno vodo. Pogovor prerase v prepir, ko jo varnostniki podučijo, da 
je $v$ karanteni in ne $v$ hotelu, ona pa odgovori, da ima kljub temu (človekove) pravice (Youtube 2020b). Spletni uporabniki jeze niso usmerili le na ta dva posameznika, temveč kar na vse izseljence in študente na študiju v tujini, jih proglasili za vzvišene in jih poimenovali 'veliki otroci' (juying); ${ }^{4}$ nehvaležno naj bi se obnašali do domovine, ki jih je sprejela (Wang, Leng 2020). Na mikroblogovski platformi Weibo sta v trenutku veliko število komentarjev pritegnili temi »Kitajska ne bo skrbela za velikanske otroke" (Zhongguo bu yang juying; Weibo 2020a) in »Nas iz Evrope tako tretirajo« (Cong Ouzhou huilaide jiu shi zhege daiyu; Weibo 2020a). Številne objave pod temama izražajo jezo do izseljencev in jih pozivajo, naj se vrnejo tja, od koder so prišli (cong na er lai hui na er qu): „Ko so zaradi epidemije doma razmere resne, zbežite $v$ tujino. Ko se vrnete, pa ne sodelujete $z$ oblastmi, imate izbruhe in zahtevate privilegije. Ali ne bi bilo bolje, da greste nazaj?« (Weibo 2020b) Tak diskurz so pograbili tudi mediji, kjer je na primer časnik Renmin Ribao, pogosto v zvezi z izseljenci, omenjal krilatico »Pri izgradnji države ne sodelujejo, škodujejo pa že od daleč巛 (Jianshe jiaxiang ni bu xing, qianli toudu di yi ming).

Vsaj deloma je tak odziv spodbudila odločitev države, da morajo povratniki, ki niso vključeni v kitajski socialni sistem, sami kriti stroške nastanitve $v$ karanteni, po poročanju okoli 70 USD na dan, po potrebi pa tudi zdravljenje (Wang, Leng 2020). $\mathrm{Na}$ tak način je sporočala, da so povratniki breme - tako zdravstvenemu sistemu kot tudi ugledu Kitajske, ki poskuša obvladati virus. Prav tako so jih državni organi in organizacije, odgovorni za stike z izseljenci (npr. kitajska veleposlaništva in Zveza izseljencev povratnikov), pozivali, da ostanejo $v$ državah naselitve in se ne vračajo na Kitajsko (Zhu 2020), kar pa pogosto ni zaleglo.

Ko se je sovražni govor tako do izseljencev kot tudi drugih tujcev, predvsem na Kitajskem živečih Afričanov, zelo razbohotil, so državne institucije začele pozivati k večji toleranci (Wan 2020; Wang, Leng 2020). Glavni mediji v državi so začeli poudarjati nesprejemljivost »ksenofobije« in pozivali k bolj »racionalnemu« naslavljanju težave naraščanja uvoženih primerov covida-19. Predvsem so spomnili, da imajo te osebe kot državljani Kitajske pravico do vrnitve, da pa morajo spoštovati mukotrpna odrekanja domačih prebivalcev, ki so uspeli zajeziti širjenje virusa (Chinadaily Online). Tudi nekateri izseljenci in študenti so na socialnih omrežjih izrazili svoje nezadovoljstvo z obravnavo, ki so je bili deležni po povratku:

[...] Zato stojimo za pravico, da se vrnemo v svojo državo. Kot prvo, delati ali študirati v tujini ne pomeni, da se odrekaš kitajskemu državljanstvu. Morda netizeni ne razumejo, da si še vedno kitajski državljan, ne glede na to, koliko let študiraš v tujini. Naše družine in prijatelji so na Kitajskem in naš potni list je kitajski. Zaradi tega

4 Izraz temelji na delu Država velikih otrok avtorja Zhihong Wuja, ki v knjigi meni, da se številni Kitajci danes ne razvijejo $v$ avtonomne osebe. Ostanejo na ravni majhnih otrok, ki zahtevajo, da vsi sledijo njihovim željam in svet razumejo zgolj v ekstremih »dobro - slabo«. V spletnem slengu se je poimenovanje »veliki otroci« uveljavilo kot sinonim za zahtevne, vase zaverovane ljudi. 
imamo enake pravice in dolžnosti kot vsak Kitajec. In če se želiš vrniti, ne potrebuješ dovoljenja netizenov. (Liu xuesheng ribao 2020)

Izključevalni govor, naperjen proti mobilnim prebivalcev Kitajske, je sicer v določeni meri podoben obtoževanju notranjih migrantov za prenašanje virusa SARS leta 2003 (Xiang 2003), vendar pa je tako negativen odnos do izseljencev nov pojav. Po uveljavitvi ekonomskih in družbenih reform v sedemdesetih letih prejšnjega stoletja so namreč izseljenci aktivno sodelovali pri projektu izgradnje nove Kitajske. Nanje so gledali kot na domoljube, ki prispevajo k modernizaciji in razvoju svoje države. (Nyiri 2005) Še zlasti v zadnjem desetletju so številni izmed njih podpirali diplomatska prizadevanja Kitajske v državah priselitve, kitajska država pa jih tudi vse bolj aktivno vključuje v državne in paradržavne strukture (glej Thunø 2018). V nasprotju s prvimi desetletji po reformah, ko je izseljevanje potekalo predvsem z zelo revnega severa ali s tradicionalno izseljenskih območij na jugu in vzhodu Kitajske (npr. v provincah Guangdong, Fujian, Zhejiang), pa je izseljevanje danes vse bolj v domeni družin srednjega razreda, ki si študij ali »zlato vizo« v tujini lahko privoščijo. Geografska mobilnost tako ni vse bolj povezana s tistimi, ki si želijo doseči socialno mobilnost, temveč s tistimi, ki so jo že dosegli (prim. Liu Farrer 2016). Morda je prav v tem treba iskati vzrok za neizmeren srd do kozmopolitskih mobilnežev z diskurzom o pravicah, ki ga je pandemična turbulenca sedaj samo še bolj spodbudila in do konca razkrila.

\section{„KITAJSKA JE IGRALA PRVI POLČAS, SVET DRUGI, KITAJSKI MIGRANTI PA IGRAMO ŽE CELOTNO IGRO ${ }^{5}$ - DRUŽBENO IZKLJUČEVANJE IN PARTICIPACIJA MED PANDEMIJO}

Raziskave diskriminacije in izključevanja migrantov se v veliki meri osredotočajo na razmere v državah priselitve in odzive tamkajšnje družbe. Vendar pa so študije mobilnosti in transnacionalizma prepričljivo pokazale, da so migracije kompleksen proces, ki poleg življenja v novi družbi zajema še kraj in državo izvora ter transnacionalne družbene prostore. Procesi izključevanja na teh lokacijah migracijskega procesa so manj znani in raziskani, vendar ključni za razumevanje mehanizmov, ki povezujejo izključevanje z mobilnostjo. Zgodovina kitajskih migracij je neločljivo povezana tako z diskriminacijo, marginalizacijo in getoizacijo kitajskih mobilnih subjektov, in to ne zgolj v državah priselitve, temveč tudi v državi izvora (npr. preganjanje izseljencev pred in med kulturno revolucijo; glej Peterson 2012). Čeprav so ti primeri pogosto potisnjeni v preteklost, pa je pandemija covid-19 razkrila, da so tovrstni mehanizmi

5 Rek »Kitajska je igrala prvi polčas, svet drugi, kitajski migranti pa celotno igro« (Guonei da shang banchan, guowai da xia banchang, haiwai huarenda quanchang) se je začel pojavljati na kitajskih izseljenskih spletnih medijih aprila 2020 in se je razširil tudi na druge kitajske medije. Nanaša se tako na pomoč, ki so jo izseljenci nudili svojim izvornim skupnostnim priselitve, kot tudi na diskriminacijo, ki so je bili v različnih okoljih prav tako deležni. 
še vedno bistveni del migracijske izkušnje kitajskih državljanov. Po izbruhu virusa SARS-CoV-2 so se kitajski migranti soočili z diskriminacijo in napadi v vseh družbenih prostorih, ki jim pripadajo. Če je izključevanje v državah priselitve potekalo na temelju rasizma, tj. pripisa kvazibiološke kategorije rase na podlagi vidnih značilnosti, pa je izključevanje $v$ skupnostih drugače formirano; glede na sedaj znane podatke se zdi, da prvo središči okoli prisotnosti virusa samega, torej kužnosti, kot tudi tveganja za ugled oz. položaj migrantske skupine $v$ družbi države naselitve, medtem ko bi lahko za izključevanje $v$ državi izvora poudarili pripadnost družbenemu razredu $v$ povezavi z mobilnostjo. Lahko bi tudi trdili, da je nujna sestavina za vsa tovrstna izključevanja prav zaznana in ne vedno dejanska mobilnost, saj postane med širjenjem virusa sumljiva tudi vsaka druga oblika mobilnosti.

Delo raziskovalca mobilnosti Noela Salazarja je osvetlilo pomembnost imaginarijev, tj. »historično podloženih, kulturno pogojenih in družbeno sporočanih reprezentacijskih skupkov« (Salazar 2012) pri ustvarjanju režimov mobilnosti (Glick Schiller, Salazar 2012). Ti omogočajo, reproducirajo in osmišljajo izkušnjo mobilnosti. Imaginariji o mobilnih ljudeh, bodisi migrantih, beguncih ali pa popotnikih, so tesno povezani $z$ videnjem teh kot nosilcev obolenj tako $v$ dobesednem kot tudi metaforičnem pomenu (Markel, Stern 2012). Takšna videnja neredko kulminirajo v predsodku o »kužnih migrantih« (Lipovec Čebron 2010), ki jih je treba odriniti na ekonomsko in družbeno margino. Pandemična turbulenca, ki jo omenja Cresswell (2020), je še posebno ugodna za razrast tovrstnih predsodkov, saj strah pred invazijo virusov organizira družbeno življenje. Režimi mobilnosti se zato vse bolj intenzivno premikajo v smeri ukinjanja mobilnosti in prikazovanja mobilnosti kot ogrožajoče, ali pa se različne oblike mobilnosti prikazujejo kot bolj ali manj upravičene in zaželene glede na dejavnike, kot so etnična ali »kulturna« pripadnost, posedovanje specifičnih veščin na trgu dela, spol itn. (Knežević Hočevar, Cukut Krilić 2019).

Odnos do mobilnosti med pandemijo tako kaže na kompleksno razmerje med dvojico »državljan - migrant«. Kot sledi iz novejšega prispevka Bridget Anderson (2019), je v središču razumevanja mobilnosti konflikt med ukoreninjenimi domačini in neumeščenimi tujci. Obravnava tega dihotomičnega razmerja zakriva, da (meddržavna) mobilnost, tj. migracija, ni »naravni« vidik procesa razlikovanja. Zabriše namreč mehanizme, ki jih uporablja država pri kategoriziranju različnih mobilnih skupin, ter prikrije podobnosti in sorodnosti med izključevanjem znotraj državljanstva in izključevanjem na podlagi državljanstva. Kot ugotavlja Mégret (2020), lahko med pandemijo opazujemo, kako država poskuša na novo interpretirati državljanstvo tako, da na novo vzpostavlja razlike med kategorijami državljanov, kar se npr. zrcali v odnosu do dvojnih državljanov ali t. i. državljanov z manjšinsko pripadnostjo. Primer kitajskih migrantov kaže na precejšnjo kompleksnost tovrstnih reinterpretacij. Tako kitajski državljani kot naturalizirani državljani kitajskega porekla so razumljeni kot potencialni prenašalci virusa $v$ državah priselitve, medtem pa tudi kitajski državljani povratniki na Kitajskem postanejo drugorazredni državljani in so prav tako skupaj z nedržavljani proglašeni za potencialne »uvožene primere virusa«. Kot pravi Mégret 
(2020), so diaspore tako dvojno ranljive, sama pa dodajam, da so najverjetneje kar večkratno, saj tudi članstvo v transnacionalni skupini, kot sem pokazala, ne nudi nujno zavetja pred izključevanjem.

Kljub temu odzivi skupin kitajskih migrantov kažejo na aktivno in aktivistično soočenje z nastalim položajem; od civilnih gibanj, ki naslavljajo in razkrivajo diskriminacijo, do vsakodnevnih dejanj, ki ščitijo svoje nove in stare skupnosti. V tem smislu lahko govorimo o 'državljanskih dejanjih' (acts of citizenship) (Isin 2008), kjer aktivna, kreativna in inovativna dejanja ter prakse posameznikov in skupin s posegi v vsakdanjem življenju izzovejo obstoječi družbeni in politični red tudi s tem, da presežejo obstoječe meje držav in družbenega življenja. Ne glede na to, kako države interpretirajo in reinterpretirajo državljanstvo, je pandemija priložnost, da se tako kitajski mobilni subjekti kot tudi drugi s tovrstnimi dejanji vzpostavijo kot resnični demokratični državljani, ki želijo in zahtevajo biti slišani in lahko spodbudijo javno razpravo o temah mobilnosti in pripadanja v sodobnih družbah.

\section{SKLEP}

Preučevanje kitajskih migracij med pandemijo razkriva povezave med mobilnostjo in delovanjem mehanizmov izključevanja, rasizma, diskriminacije in stigme. Te družbene pojave lahko opazujemo na različnih lokacijah migracijskega procesa in ne le na eni (npr. državi priselitve), kar je kljub pozivom po večprizoriščni etnografiji in transnacionalni in mobilnostni analitični opni še vedno precej »običajna« metoda migracijskih študij. Kot sledi iz članka, so v samem središču različnih vrst izključevanj mobilnost in z njo kulturno, historično in družbeno pogojeni imaginariji, ki tako kitajske kot tudi druge mobilne posameznike in skupine nenehno vzpostavljajo kot drugačne in »neumeščene«, v času izrednih obdobij, kot je na primer pandemija, pa tudi ogrožajoče. Tovrstno izključevanje sicer na različnih delih migracijskega procesa prevzema različne oblike $-v$ državah izselitve se pojavlja kot diskriminacija na temelju pripisane »rase«, med pripadniki transnacionalne skupnosti kot stigma zaradi bolezni, v izvorni državi kot diskriminacija, ki izhaja iz pripisane kozmopolitskosti in pripadnosti privilegiranemu družbenemu razredu. $V$ vseh teh procesih pa se $v$ pandemiji mobilnost vzpostavi kot poglavitni marker, ki tovrstne konstrukcije osmišlja v dani socialni situaciji. Posledice so za migrante tako neposredne kot posredne. Med neposrednimi opisujem številne oblike izključevanj, od fizičnega in družbenega distanciranja do različnih oblik napadov. Med posrednimi pa je treba poudariti reinterpretacijo odnosa med državljani in nedržavljani, kjer so določene (mobilne) skupine državljanov tarča enakih oblik izključevanj, ki so bile v preteklosti usmerjene proti nedržavljanom (predvsem migrantom). Oblike odpora proti tem oblikam izključevanj so zato hkrati odpor proti zoževanju mobilnosti kot družbene prakse, kot tudi nasprotovanje kategoriziranju zaželenih in manj zaželenih državljanov in soprebivalcev. Obravnava kitajskih migrantov $v$ pandemiji covida-19 razkriva, da je mobilnost, 
čeprav ključna lastnost sodobnosti, še vedno dojeta kot tako ali drugače ogrožajoča, takšno razumevanje pa presega nacionalne meje in dihotomijo med izvorno državo in državo priselitve in ga je, tako kot virus, le stežka zaustaviti.

\section{LITERATURA}

Anderson, Bridget (2019). New Directions in Migration Studies: Towards Methodological De-nationalism. Comparative Migration Studies 7/36, https://comparativemigrationstudies.springeropen.com/articles/10.1186/s40878-019-0140-8\#citeas (1. 2. 2020).

Barrett, Ron, Brown Peter J. (2008). Stigma in the Time of Influenza: Social and Institutional Responses to Pandemic Emergencies. The Journal of Infectious Diseases 197, 34-37.

Busby, Mattha (2020). Vietnamese Curator Dropped because of 'Coronavirus Prejudice', https://www.theguardian.com/world/2020/mar/05/vietnamese-curator-dropped-because-of-coronavirus-prejudice (14. 4. 2020).

Campbell, Lucy (2020). Chinese in UK Report 'Shocking' Levels of Racism after Coronavirus Outbreak, https://www.theguardian.com/uk-news/2020/feb/09/ chinese-in-uk-report-shocking-levels-of-racism-after-coronavirus-outbreak (13. 3. 2020).

Ceccagno, Antonella, Salvati, Alessandra (2020). The Chinese 'Grid Reaction' in Prato, Italy, https://www.compas.ox.ac.uk/2020/the-chinese-grid-reaction-in-prato-italy/ (30. 4. 2020).

Chen, Laurie (2020). I am not a Virus, I am a Human Being: Italian-Chinese Man's Video Spreads Anti-racist Message on Social Media, https://www.scmp.com/ news/china/society/article/3050499/i-am-not-virus-i-am-human-being-italian-chinese-mans-video (13. 4. 2020).

Cheung, Helier, Zhaoyin, Feng, Boer, Deng (2020). Coronavirus: What Attacks on Asians Reveal about American Identity, https://www.bbc.com/news/world-us-canada-52714804 (1. 6. 2020).

ChinaDaily Online (2020). Returnees must Play their Part in Virus Control:China DailyEditorial, https://www.chinadaily.com.cn/a/202003/18/WS5e71f9a1a3101282172802d6. html (15. 4. 2020).

CNNPhilippines (2020). OFW in Italy Attacked, Mistaken as Chinese National Amid Coronavirus Outbreak, https://cnnphilippines.com/news/2020/3/9/OFW-in-Italy-attacked-mistaken-as-Chinese-national-coronavirus.html (1. 4. 2020).

Coste, Vincente (2020). Coronavirus: France Faces 'Epidemic' of Anti-Asian Racism, https://www.euronews.com/2020/02/03/coronavirus-france-faces-epidemic-of-anti-asian-racism (13. 4. 2020).

Cresswell, Tim (2006). On the Move: Mobility in the Modern World. New York, London: Routledge. 
Cresswell, Tim (2020). Mobility: The Lifeblood of Modernity and the Virus that Threatens to Undo it, https://en.forumviesmobiles.org/2020/03/18/mobility-lifeblood-modernity-and-virus-threatens-undo-it-13266 (2. 4. 2020).

Glick Schiller, Nina, Salazar, Noel B. (2012). Regimes of Mobility across the Globe. Journal of Ethnic and Migration Studies 39/2, 183-200.

Govan, Fiona (2020). Is Coronavirus Paranoia Fuelling Racism against the Chinese in Spain? https://www.thelocal.es/20200131/is-the-coronavirus-is-fuelling-racismagainst-chinos-in-spain (19. 4. 2020).

Hung, Ho-fung (2004). The Politics of SARS: Containing the Perils of Globalization by more Globalization. Asian Perspective 28/1, 19-44.

Ipsos Mori (2020). COVID-19 - One in Seven People would avoid People of Chinese Origin or Appearance, https://www.ipsos.com/ipsos-mori/en-uk/covid-19-one-seven-people-would-avoid-people-chinese-origin-or-appearance (17. 4. 2020).

Kalisch, Philip A. (1972). The Black Death in Chinatown: Plague and Politics in San Francisco 1900-1904. Arizona and the West 14/2, 113-136.

Knežević, Hočevar, Duška, Cukut Krilić, Sanja (2019). Contestable Demographic Reasoning Regarding Labour Mobility and Migration. Dve Domovini / Two Homelands 50, 131-146.

Leung, Carrianne (2008). The Yellow Peril Revisited: The Impact of SARS on Chinese and Southeast Asian Communities. Resources for Feminist Research 33/1-2, 1-39.

Lipovec Čebron, Uršula (2010). The Construction of a Health Uninsurant: People without Medical Citizenship as seen by some Slovene Health Workers. Stud. Ethnol. Croat. 22, 187-212.

Liu Farrer, Gracia (2016). Migration as Class-based Consumption: The Emigration of the Rich in Contemporary China. The China Quarterly 226, 499-518.

Liu, Yuebao (2020). Coronavirus Prompts "Hysterical, Shameful" Sinophobia in Italy, https://www.aljazeera.com/news/2020/02/coronavirus-prompts-hysterical-shameful-sinophobia-italy-200218071444233.html (22. 3. 2020).

Liuxuesheng ri bao (2020). Liuxuesheng tongku! Zai guowai bei da bei ma 'Zhongguo bindu', huiguo beima 'qianli tudou'..., https://mp.weixin.qq.com/s?__bi$z=M z A 5 N z \mid w M j Q z M A==\& m i d=2650038946 \& i d x=1 \& s n=b 8 d 026 a d c b a f d 6$ 4dd8cb47d2062a2eb0\&chksm =88a4bb33bfd332259cc12f289d1a77e9ff5eda4246ca5b9805326a92807b14214e2936788476\&mpshare $=1 \&$ scene $=1 \& \mathrm{~s}-$ rcid $=\&$ sharer_sharetime $=1585175201657 \&$ sharer_shareid $=c c 2600 \mathrm{~b}$ 3b47159e2279edf81b59e7bcf\&exportkey=AuszRNznKDPIYk\%2F1ZArokf4\%3D\&pass_ticket=ppBI2RfPuX0cruNjlK4KdglGIChXhtNUIgmW2QSIulzq\%2Fsa76koDFIJrxmuwAPX4\#rd (22. 4. 2020).

Macquire, Eoghan (2020). Anti-Asian Hate Continues to Spread Online Amid COVID-19 Pandemic, https://www.aljazeera.com/news/2020/04/anti-asian-hate-continues-spread-online-covid-19-pandemic-200405063015286.html (10. 4. 2020). 
Markel, Howard, Stern, Alexandra Minna (2012). The Foreignness of Germs: The Persistent Association of Immigrants and Disease in American Society. Race and Immigration in the United States (ur. Paul Spickard). New York: Routledge, 203-229. Mégret, Frederic (2020). COVID-19 Symposium: Returning "Home" - Nationalist International Law in the Time of the Coronavirus, http://opiniojuris.org/2020/03/30/ covid-19-symposium-returning-home-nationalist-international-law-in-the-time-of-the-coronavirus/ (12. 4. 2020).

Nyiri, Pal (2005). The 'New Migrant': State and Market Constructions of Modernity and Patriotism. China Inside Out: Contemporary Chinese Nationalism and Transnationalism (ur. Pal Nyiri, Joana Breidenbach). Budimpešta, New York: Central European University Press, 141-176.

Ognibene, Silvia (2020). From Zero to Hero: Italy's Chinese Help Beat Coronavirus, https://www.reuters.com/article/us-health-coronavirus-italy-chinese/from-zero-to-hero-italys-chinese-help-beat-coronavirus-idUSKBN21I3I8 (12. 4. 2020).

Pescosolido, Bernice A., Martin, Jack K. (2015). The Stigma Complex. Annual Review of Sociology 41, 87-116.

Peterson, Glen (2012). Overseas Chinese in the People's Republic of China. London, New York: Routledge.

Puente, David (2020). »Sti c*z dei cinesi ... morissero perlomeno solo loro«. Il post sul coronavirus del sindaco bergamasco e le scuse pubbliche firmate, https://www. open.online/2020/02/22/sti-cz-dei-cinesi-morissero-perlomeno-solo-loro-il-post-sul-coronavirus-del-sindaco-bergamasco-e-le-scuse-pubbliche-firmate/ (12. 3. 2020).

Qiu, Yue, Yuan, Bo (ur.) (2020). Xingguan feiyan shuru xing bingli zengduo: Bu gai yaomo hua guiguo renyuan, http://yuqing.people.com.cn/n1/2020/0323/c20904331644613.html (13. 4. 2020).

Reuters (2020). China Reports no new Local Coronavirus Transmissions for first Time, https://www.reuters.com/article/us-health-coronavirus-china/china-reports-nonew-local-coronavirus-transmissions-for-first-time-idUSKBN216085 (10. 4. 2020).

Salazar, Noel B. (2012). Imagining (Im)mobility at the 'End of the World'. Technologies of Mobility in the Americas (ur. Phillip Vannini et al.). New York: Peter Lang, 237-254.

Stolton, Samuel (2020). COVID-19 Crisis Triggers EU Racism against Asians, Rights Agency Says, https://www.euractiv.com/section/global-europe/news/covid-19-crisis-triggers-eu-racism-against-asians-rights-agency-says/ (1. 6. 2020).

The Straits Time (2020). 'Coronavirus' Sprayed on Japanese Restaurant in Paris, https://www.straitstimes.com/world/europe/coronavirus-sprayed-on-japanese-restaurant-in-paris (12.4. 2020).

Thunø, Mette (2018). China's New Global Position: Changing Policies towards the Chinese Diaspora in the Twenty-first Century. China's Rise and the Chinese Overseas (ur. Bernard Wong, Chee-Beng Tan). New York: Routledge, 184-208. 
Wan, Tingting (2020). Renmin ruiping: Shuo guiguo renyuan 'Qianli toudu yi ming' hen bu heshi, http://m.thepaper.cn/newsDetail_forward_6568051 (1. 4. 2020).

Wang, Qi, Leng, Shumei (2020). Mixed Feelings toward overseas Chinese Returning to Escape COVID-19, http://www.globaltimes.cn/content/1183025.shtml (13. 4. 2020).

Weale, Sally (2020). Chinese students Flee UK after 'Maskaphobia' Triggered Racist Attacks, https://www.theguardian.com/education/2020/mar/17/chinese-students-flee-uk-after-maskaphobia-triggered-racist-attacks (13. 4. 2020).

Weibo (2020a). Zhongguo bu yang, https://m.weibo.cn/search?containerid=23152 2type\%3D1\%26t\%3D10\%26q\%3D\%23中国不养巨婴\%23\&extparam=\%23中国 不养巨婴\%23\&luicode $=10000011 \& l f i d=231522$ type\%3D1\%26t\%3D10\%26q\% 3D\%23我们中国\%20不养巨婴\%23 (12.4.2020).

Weibo (2020b). Cong Ouzhou huilade jiu zhe daiyu, https://m.weibo.cn/search?containerid $=231522$ type $\% 3 \mathrm{D} 1 \% 26 \mathrm{t} \% 3 \mathrm{D} 10 \% 26 \mathrm{q} \% 3 \mathrm{D} \% 23$ 我欧洲回来的 就这待遇\%3F\%23\&extparam=\%23我欧洲回来的就这待遇\%3F\%23\&luicode $=10000011 \&$ Ifid $=231522$ type\%3D1\%26t\%3D10\%26q\%3D\%23澳籍返京女子 不隔离外出跑步\%23\&featurecode $=20000180 \% C 2 \% A 0$ (12. 4. 2020).

Weicheng (2020). Dujia! Aodili quezhen Zhongguo funu nüer qin shu: Cong Yidali youlun dao Weiyena yiyuan de lücheng, https://mp.weixin.qq.com/s/pMjw68pKCC5E-aghYJMGQA (12. 4. 2020).

Wimmer, Andreas, Glick Schiller, Nina (2002). Methodological Nationalism and Beyond: Nation-state Building, Migration and the Social Sciences. Global Networks 2/4, 301-334.

Xiang, Biao (2003). SARS and Migrant Workers in China. Asian and Pacific Migration Journal 12/4, 467- 499.

Youtube (2020a). Women xong Ouzhou huilaide jiu zhedaiyu? Yidali gui Huaren xian dengdai qu tiaojian jianlou zhiwen gongzuo renyuan, https://www.youtube. com/watch?v=YDYvFidlxrc (24. 4. 2020).

Youtube (2020b). Nüzi bei geli jianchi yao he kuangquan shui, minjing: Bu shi jiudian, https://www.youtube.com/watch?v=JUMsGXm5JyE (27. 4. 2020).

Zhou, Kangliang (2011). The Power of the Chinese Netizen? How Microblogging is Changing Chinese Journalism. Reuters Institute Fellowship Paper.

Zhu, Lingjun (2020). Hai zai Yidali de Qingtian ren zai jiujie shenme?, https://www. jfdaily.com/wx/detail.do?id=219845 (12.4. 2020). 


\section{SUMMARY}

\section{CHINESE MIGRANTS AND COVID-19: MOBILITY AND EXCLUSION IN THE TIME OF PANDEMIC Martina BOFULIN}

The article analyzes the practices of exclusion and discrimination against Chinese migrants in the time of the COVID-19 pandemic. Because the COVID-19 outbreak originated in the People's Republic of China, Chinese migrants have been in the center of discourses on the pandemic in all critical locations of the migration process: in the countries of settlement, the country of origin as well as in their transnational communities.

In the countries of settlement, Chinese migrants faced various forms of exclusion based on racism that have thus targeted all people whose phenotype has been deemed as "Chinese". For this reason, many Japanese, Filipinos, and Koreans became targets of discrimination as well. These acts included online bullying, distancing, and awkward behavior, the decline of visits to Chinese restaurants and shops as well as physical attacks. Some Chinese groups and communities sought to push back against this treatment by starting online and offline campaigns against racism and prejudice (e.g., \#JeNeSuisPasUnVirus).

On the other hand, the people who contracted the virus were also targets within their transnational communities. While information on these forms of exclusion is scarce, the author recounts one such case where death by COVID-19 prompted intense pressure in the form of rumors, online commenting and bullying from the community towards the victim's family. To defend against the claims of reckless behavior, the family resorted to a public rebuttal through social media.

Lastly, the article investigates the cases of the strong exclusionary discourse against Chinese migrants who returned to China on the eve of the purported victory over the virus transmission, thus becoming the suspects of virus importation. The exclusionary discourse that ensued was led by online users, so-called netizens, who can exert a strong influence on the lives of their targets. There was a weak resistance against these attacks by migrant returnees, but eventually, the Chinese mainstream media addressed the dangerous discourse, calling for more tolerance.

By highlighting the mechanisms of exclusion towards Chinese migrants along the entire migration process as well as the resistance to exclusion, the author reveals how exclusion is part and parcel of Chinese migration, which becomes only more evident in the time of the pandemic. She argues that while the exclusions experienced at various "locations" along the migration process are differently structured, they nonetheless all rest on the mobility imaginaries that various groups hold about Chinese migrants. She also speculates that the effects of these acts of exclusion are reinterpretations of the dichotomic relationship in the conceptual pair "migrant-citizen". In contrast, the resistance against such exclusions by Chinese migrants gives hope that such "acts of citizenship" (Isin 2008) can trigger much needed public debate on the connection between exclusion and mobility. 